\title{
線形計画法を用いた耕畜連携システムの環境・経済性評価法の確立 一国家レベルでの水田利活用の検討一
}

\author{
西田俊也 ${ }^{1} \cdot$ 大石風人 $^{1} \cdot$ 長命洋佑 ${ }^{1} \cdot$ 熊谷 $^{\text {元 }^{1} \cdot \text { 広岡博之 }}{ }^{1}$ \\ 1 京都大学大学院農学研究科, 京都市左京区 606-8502
}

(2013. 3. 25 受付, 2013. 9. 2 受理)

\begin{abstract}
要 約＼cjkstart国家しベルで耕音連携による飼料生産を線形計画法モデルにより評価した. とりわけ, 本研究で は水田における飼料生産に焦点を当てた，家畜については，乳用種倠牛，乳用種去勢牛，黒毛和種，交雑種， ブタ, 採卵鶏およびブロイラ一を取り上げ, 作物については, 水田の利用を想定し, 水田牧草, 稲発酵粗飼料, 飼料用米および食用米を考慮した，目的関数を日本全体における関連農家（畜産農家と水田利用農家）の総 利益とし，国全体の環境影響や労働時間を抑えつつ，経済性を最大化させる最適家畜頭数および耕地面積配 分の算出を行った，関連農家の総利益が最大になったのは，家畜に関しては，黒毛和種および採卵䳕の頭羽 数を増加させ, それ以外の家畜の頭羽数を削減した場合, また耕作地に関しては, 食用米の代わりに稲発酵 粗飼料を作付けした場合であった，さらに代替条件として，余剩窒素および温室効果ガス排出量の削減目標， 水田利用に関する補助金，濃厚飼料価格，畜種ごとの飼料用米生産費の違いが最適配分に与える影響を評価 した.
\end{abstract}

日本畜産学会報 84 (4), 475-486, 2013

元来，畜産は作物生産からの副産物や残椬を飼料として 利用し，鿓尿を堆肥として農地還元するなど作物生産と深 く結びつきながら資源循環の点で重要な役割を果たしてき た.しかし 20 世紀半ばから, 多くの先進国では人口増加 による食料需要の増加に対応するため, 生産効率を重視し た規模拡大と専業化が進んだ結果, 作物生産と家畜生産は 分離して営まれるようになり (Naylor 52005 ; Ruselle 5 2007), 大量の飼料が畜産経営体の外部から購入され るようになった. 一方, 家畜からの䔬尿は農地に還元され ず, しばしば環境污染源として深刻な環境問題を引き起こ している.さらに近年では, 飼料として利用されていた作 物が，新たにバイオエタノール生産に利用されるようにな り, 飼料作物をめぐる人間と家畜の競合問題も生じている. このような畜産由来の環境問題および飼料作物をめぐる人 間亡家畜との競合問題を同時に解決する方法として, 分離 され專業化されてきた作物生産と家畜生産を再び結びつけ る新しい耕音連携生産システムの構築が, 先進国を中心に 模索され始めている (Schiere 52002 ; Naylor 52005 ; Russelle 52007 ; Herrero 5 2010).このような耕畜 連携生産システムを構築するためには，(1）システム内 部の栄養素循環を最大限利用する，(2) システム外から 購入する飼料や化学肥料を減少させる, (3) 余剩栄養素 や環境に排泄される温室効果ガスを低減する，(4) 経営 的にも持続可能である, ことが求められる.
近年，わが国においては，飼料自給率の向上と水田の有 効利用の手段として飼料イネの栽培が注目されている（千 円と荻野 2012)。飼料イネは利用方法によって稲発酵粗 飼料 (WCS) および飼料用米に大別される.WCS は, 飼 料用のイネを黄熟期前期に籾茎葉ごと収穫し，一般的に ラップサイレージの形で調整・保存され, 主にウシの粗飼 料として利用されている。，一方，飼料用米は，飼料イネの 子実部のみを利用した飼料のことで, トウモロコシなどの 輸入穀物の代わりに濃厚飼料としてウシ, ブタ, ニワトリ に利用されている. 近年, 飼料イネ (WCS と飼料用米) 生 産は農業者戸別所得補償制度における補助金（2012 年現 在 80,000 円/10a）によって作付面積が急速に増加し, 2011 年にはWCS の作付面積は全国で 23,123 ha, 飼料 用米の面積は33,939 ha となっている（千田と荻野 2012)。しかしながら, 補助金の多寊は一過性で, 社会情 勢によつて変化する可能性があるため, 飼料イネの生産が メリットを生む補助金分岐点を明らかにする必要性がある (Kikuhara と Hirooka 2009 ; 広岡亡大石 2010)。これ まで，WCS や飼料用米に関する研究は，主に家畜への給 与試験による消化性を調べた研究が多く(小林と柳川 1984 ; 古賀ら 2003 ; 因野ら 2007 ; 勝俣ら 2009 など), 経済性や環境負荷の評価にまで踏み込んだ研究の数は限 られている（藤本と恒川 2007 ; Kikuhara と Hirooka 2009 ; 千田と荻野 2012).

連絡者：広岡博之（fax: 075-753-6363, e-mail : hirooka@kais.kyoto-u.ac.jp） 
そこで本研究では, 水田における飼料イネ生産を対象に, 線形計画法を用いて飼料別耕作地面積亡家畜頭羽数の最適 配分を検討し，さらに余剩窒素排出や温室効果ガスの削減 目標, 補助金の価格, 飼料用米を給与する畜種別販売価格 および濃厚飼料の価格の違いが, 飼料別耕作地作付面積と 家畜頭羽数の最適配分にどのように影響するかを調べるこ とを目的とした.

\section{材料および方法}

\section{1. システム境界の設定}

本研究においては, 水田における飼料イネ生産（ここで は専用種を想定）を中心に，飼料の供給面での作物生産と 需要面での家畜生産を想定し, 最適な耕畜連携生産システ ムの在り方を検討した，すなわち，水田利用では従来の主 食用米生産に加えて WCS 亡飼料用米および水田牧草（こ こではイタリアンライグラスを想定）の生産を想定し（い ずれも自然条件の制約要因は無視して，単作と仮定），家 畜については, 乳用種雌牛 (泌乳牛, 乾乳牛, 更新雌子牛), 乳用種去勢育成牛, 乳用種去勢肥育牛, 黒毛和種繁殖牛, 黒毛和種肥育牛, 交雑種肥育牛 $\left(F_{1}\right)$, ブタ, 採卵鵎およ びブロイラ一を想定した．また，本研究では家畜の飼料摂 取量と給与飼料生産の需給バランスの維持を想定している ために，過不足が生じないように水田による飼料生産以外 に国産飼料作物（作物統計（農林水産省 2012a）に記載 されているイタリアンライグラス, 青刚りトウモロコシ, ソルゴーを想定）と購入粗飼料および購入濃厚飼料（購入
飼料とは輸入・国産にかかわらずシステム外からの購入し た飼料を指す）を考慮した（図 1)。さらに，飼料用米に 関しては，家畜種別生産価格の違いを検討するため, ウシ 用飼料用米，ブ夕用飼料用米，二ワトリ用飼料用米亡区分 した. なお, 本研究では, 水田の利用と耕畜連携の推進に 焦点を当てているため, 水田での主食用作物（麦類や大豆） の生産や水田以外の畑作に関してはシステム境界の外と考 えて, 分析からは除外した。

2. ベース条件における線形計画法の目的関数と制約 関数

現状での生産を想定した制約条件を設定し，それらの制 約条件下において家畜および耕作地から得られる利益を最 大とする飼養頭羽数および耕作地面積に対する最適解を線 形計画法により求め, 本研究におけるべース条件と設定し た.

家畜種別頭羽数, 作物種別耕作地面積, 国産飼料作物量 および輸入濃厚飼料量に関するべクトルメを式(1)のよう に定義する.

$$
\boldsymbol{X}=\left(\mathrm{x}_{1}, \mathrm{x}_{2}, \mathrm{x}_{3}, \mathrm{x}_{4}, \cdots, \mathrm{x}_{21}\right)
$$

式(1)において $X$ ベクトル要素は表 1 の各項目番号の家 畜頭羽数, 耕作地面積, 購入飼料量を示している. また各 部門からの利益に関するべクトルを c ベクトル (表 1 に示 す Benefits）と定義し, この総利益を求める目的関数 (Z) を最大化することを考えた。

$$
Z=\sum_{i=1}^{21} C_{i} X_{i} \rightarrow \text { 最大化 }
$$

\section{Crop production}

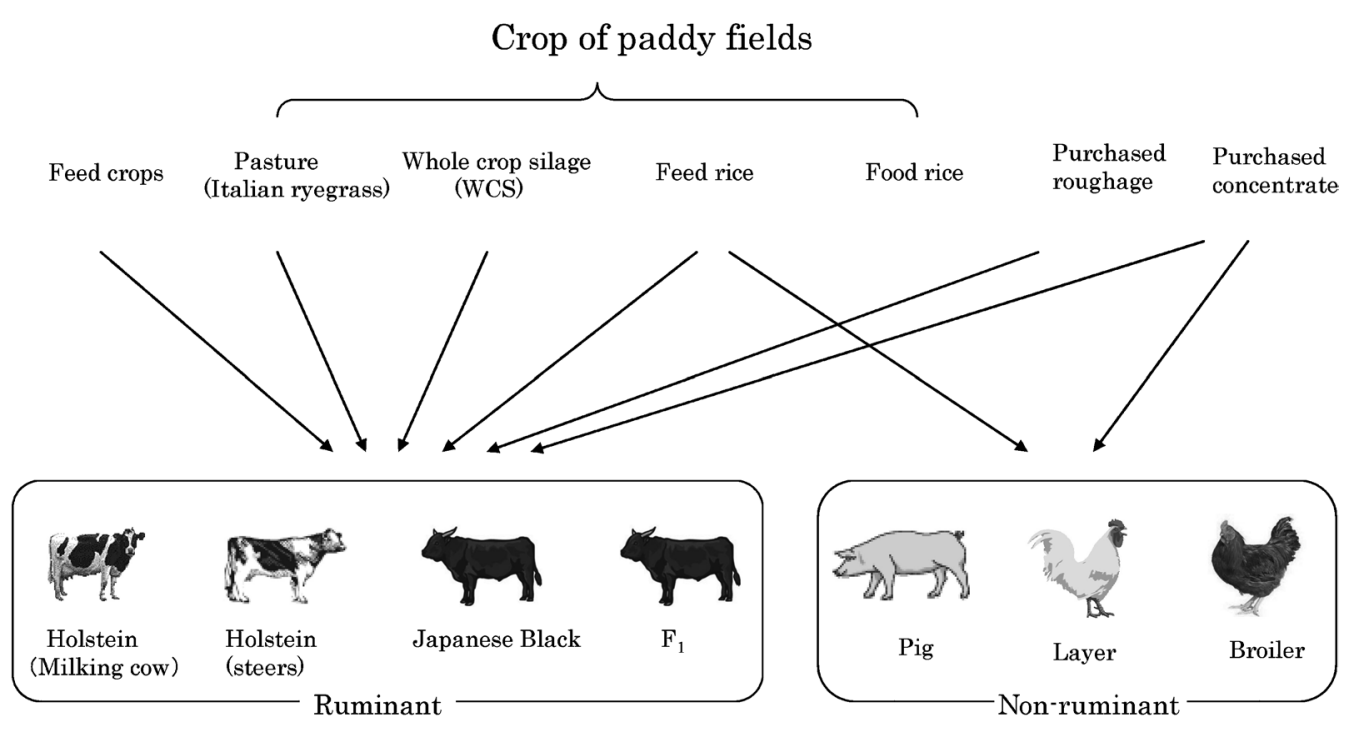

\section{Animal production}

Figure 1 Crop and animal production in this study. The arrows in the figure indicate TDN or ME flows. 
制約条件 $\boldsymbol{A X} \leq$ or $=$ or $\geq \boldsymbol{b}$

$$
x \geq 0
$$

ここで，Aは技術係数行列， $\boldsymbol{b}$ は制約条件のべクトルであ る. 主要な技術係数行列は表 1 の左辺に示し，またその 推定の根拠は補足説明で述べることとした．制約条件とし ては, 畜種全体の TDN 要求量あるいは ME 要求量の総和
が対応する給与飼料の供給量の総和と等しくなる（すなわ ちバランス量がゼロ）ように制約を付加し，また環境影響 と総労働時間は現状の水準以下になるように制約を加えた (表 1).その他の制約としては, 飼料自給率を維持させる ため，濃厚飼料における飼料用米の割合および粗飼料にお ける牧草とWCSの割合を現状以上とした，また，各家畜

Table 1 Tableau representation for linear programming in this study

\begin{tabular}{|c|c|c|c|c|c|c|c|c|c|c|c|c|c|}
\hline & $\begin{array}{l}1 \text { Holstein } \\
\text { (Milking ) }\end{array}$ & \multicolumn{2}{|c|}{$\begin{array}{l}2 \text { Holstein } \\
\text { (Fattening) }\end{array}$} & \multicolumn{2}{|c|}{$\begin{array}{l}3 \text { Holstein } \\
\text { (Growing) }\end{array}$} & $\begin{array}{l}4 \mathrm{JB}^{1} \\
\text { (Cow) }\end{array}$ & \multicolumn{2}{|c|}{$\begin{array}{c}5 \mathrm{JB} \\
\text { (Fattening) }\end{array}$} & \multicolumn{2}{|c|}{$\begin{array}{c}6 F_{1}^{2} \\
\text { (Fattening) }\end{array}$} & \multicolumn{2}{|c|}{$\begin{array}{c}7 F_{1} \\
\text { (Growing) }\end{array}$} & 8 Pig \\
\hline $\begin{array}{l}\text { Cattle TDN } \\
\text { (Concentrate) }\end{array}$ & -2711 & \multicolumn{2}{|c|}{-2225} & \multicolumn{2}{|c|}{-376} & -602 & \multicolumn{2}{|c|}{-1880} & \multicolumn{2}{|c|}{-2085} & \multicolumn{2}{|c|}{-376} & 0 \\
\hline $\begin{array}{l}\text { Cattle TDN } \\
\text { (Roughage) }\end{array}$ & -2650 & \multicolumn{2}{|c|}{-184} & \multicolumn{2}{|c|}{-740} & -1684 & \multicolumn{2}{|c|}{-179} & \multicolumn{2}{|c|}{-162} & \multicolumn{2}{|c|}{-740} & 0 \\
\hline Pig TDN production & 0 & \multirow{2}{*}{\multicolumn{2}{|c|}{$\begin{array}{l}0 \\
0\end{array}$}} & \multicolumn{2}{|c|}{0} & 0 & \multicolumn{2}{|c|}{0} & \multicolumn{2}{|c|}{0} & \multicolumn{2}{|c|}{0} & -667 \\
\hline Poultry ME production & 0 & \multirow{2}{*}{\multicolumn{2}{|c|}{$\begin{array}{c}0 \\
44.41\end{array}$}} & \multicolumn{2}{|c|}{0} & 0 & 0 & ) & 0 & & 0 & 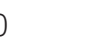 & 0 \\
\hline Nitrogen excretion & 96.23 & & & & 0.88 & 86.8 & 40.6 & 63 & 44 & 41 & 12.2 & 27 & 7.88 \\
\hline GHG emission & 6986 & 150 & & & 6.21 & $247 \mathrm{~s}$ & 150 & 06 & 150 & 06 & 866 & 36 & 140 \\
\hline Labor time & 99.00 & 16.6 & & & .18 & 93.4 & 50.4 & 46 & 27. & .09 & 9.8 & 86 & 2.80 \\
\hline Energy use & 7769 & 218 & & & 18 & 180 & 218 & 8 & 21 & 18 & $21 \varepsilon$ & 18 & 950 \\
\hline Benefits & 531891 & 1118 & & & 198 & $2371 \varepsilon$ & 3331 & 173 & 3068 & 864 & 1084 & 482 & 32792 \\
\hline Unit & head & hea & & & ead & heac & hea & & hea & $\mathrm{ad}$ & hea & $\mathrm{ad}$ & head \\
\hline & 9 Layer 10 & 0 Broilers & $\begin{array}{l}11 \mathrm{Fe} \\
\mathrm{cror}\end{array}$ & $\begin{array}{l}\text { Feed } \\
\text { ops }\end{array}$ & $\begin{array}{l}12 \text { Past } \\
\text { paddy }\end{array}$ & $\begin{array}{l}\text { ture in } \\
\text { / fields }\end{array}$ & 13 WCS & $\begin{array}{l}14 \mathrm{Fe} \\
\text { (For }\end{array}$ & $\begin{array}{l}\text { ed rice } \\
\text { cattle) }\end{array}$ & $\begin{array}{l}15 \text { Fee } \\
\text { (For }\end{array}$ & $\begin{array}{l}\text { ed rice } \\
\text { r pig) }\end{array}$ & $\begin{array}{l}16 \mathrm{Fe} \\
\text { (For } \mathrm{p}\end{array}$ & $\begin{array}{l}\text { eed rice } \\
\text { poultry) }\end{array}$ \\
\hline $\begin{array}{l}\text { Cattle TDN } \\
\text { (Concentrate) }\end{array}$ & 0 & 0 & 0 & כ & 0 & & 0 & & 439 & & 0 & & 0 \\
\hline $\begin{array}{l}\text { Cattle TDN } \\
\text { (Roughage) }\end{array}$ & 0 & 0 & 401 & 10 & $37 \mathrm{~s}$ & & 5890 & & 0 & & 0 & & 0 \\
\hline Pig TDN production & 0 & 0 & 0 & 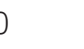 & 0 & & 0 & & 0 & & 505 & & 0 \\
\hline Poultry ME production & -203 & -273 & 0 & 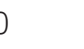 & 0 & & 0 & & 0 & & 0 & & 5184 \\
\hline Nitrogen excretion & 0.67 & 0.54 & -16 & 64 & -1 & & -150 & & 150 & & 150 & & -150 \\
\hline GHG emission & 5.12 & 3.86 & 180 & 06 & 186 & & 11354 & & 354 & & 354 & & 1354 \\
\hline Labor time & 0.45 & 0.14 & 137. & .03 & 13 & & 203 & & 82 & & 82 & & 182 \\
\hline Energy use & 48 & 51 & 653 & 35 & 676 & & 6387 & & 397 & & 397 & & 6397 \\
\hline Benefits & 2573 & 1963 & -301 & 1079 & 631 & & 225000 & 257 & 7640 & & 7640 & & 57640 \\
\hline Unit & head & head & ha & a & ha & & ha & & ha & & ha & & ha \\
\hline & $\begin{array}{l}17 \text { Food } \\
\text { rice }\end{array}$ & $\begin{array}{l}18 \text { Purch } \\
\text { concent }\end{array}$ & $\begin{array}{l}\text { nased } \\
\text { trate }\end{array}$ & $\begin{array}{r}19 P \\
\text { ro }\end{array}$ & $\begin{array}{l}\text { Purchas } \\
\text { pughage }\end{array}$ & $\begin{array}{l}\text { sed } 2 \\
\text { e }\end{array}$ & $\begin{array}{l}0 \text { Purchase } \\
\text { feed (Pig) }\end{array}$ & ed $\begin{array}{l}2 \\
\mathrm{fe}\end{array}$ & $\begin{array}{l}1 \text { Purch } \\
\text { eed (Pou }\end{array}$ & $\begin{array}{l}\text { hased } \\
\text { ultry) }\end{array}$ & Type & Cons & straints \\
\hline $\begin{array}{l}\text { Cattle TDN } \\
\text { (Concentrate) }\end{array}$ & 0 & 0.75 & & & 0 & & 0 & & 0 & & $=$ & & 0 \\
\hline $\begin{array}{l}\text { Cattle TDN } \\
\text { (Roughage) }\end{array}$ & 0 & 0 & & & 0.52 & & 0 & & 0 & & $=$ & & 0 \\
\hline Pig TDN production & 0 & 0 & & & 0 & & 0.79 & & 0 & & $=$ & & 0 \\
\hline Poultry ME production & 0 & 0 & & & 0 & & 0 & & 11.63 & & $=$ & & 0 \\
\hline Nitrogen excretion & -6.31 & 0 & & & 0 & & 0 & & 0 & & $\leqq$ & & urrent $^{3}$ \\
\hline GHG emission & 11354 & 0.39 & & & 0.24 & & 0.4 & & 0.37 & & $\leqq$ & & urrent \\
\hline Labor time & 260 & 0 & & & 0 & & 0 & & 0 & & $\leqq$ & & urrent \\
\hline Energy use & 9138 & 5.8 & & & 3.5 & & 5.9 & & 5.6 & & $\leqq$ & & urrent \\
\hline Benefits & 398900 & -40 & & & -50 & & -40 & & -40 & & & & \\
\hline Unit & ha & $\mathrm{kg}$ & & & kg & & kg & & $\mathrm{kg}$ & & & & \\
\hline
\end{tabular}

1 Japanese Black cattle

${ }^{2}$ Crossbreds of Japanese Black sire and Holstein dam

${ }^{3}$ Current situation 
頭羽数においては乳用種肥育牛および $F_{1}$ 以外の家畜頭羽 数の变動幅の制約値を現状の $\pm 20 \%$ とし, 乳用種去勢肥 育牛亡乳用種去勢育成牛, 黒毛和種繁殖牛亡黒毛和種肥育 牛および $F_{1}$ 肥育牛と $F_{1}$ 育成牛の頭数のバランスを現状の まま維持することとした，乳用種雌牛は，次世代の乳用種 去勢牛（育成牛も含む）亡同数の乳用種雌牛および $F_{1}$ （雌 雄の肥育牛亡育成牛の和）を生産すると仮定し, 乳用種雌 牛頭数 $=$ 乳用種去勢牛頭数 $\times 2+F_{1}$ 頭数亡なるように制 約を付加した. ここで，乳用種去勢牛頭数に2を乗じた のは乳用種倠牛が生産する乳用種牛の雌雄を $1: 1$ 亡想定 したためである. また西田ら（2013）の $F_{1}$ 生産を想定し た乳牛集団の牛群モデルから, 乳牛の集団を維持するため には乳牛における黒毛和種精子交配率を $33.8 \%$ 以下にす る必要があると推定されたため, F 1 の頭数は乳牛の $33.8 \%$ 以下になるようにした，以上の家畜生産からの利 益や技術係数は, 年単位である作物生産に合わせるために, 畜種でとの生産サイクルの相違を補正して 1 年単位で算 出した.

一方, 耕作地面積に関しては, 水田の利用配分に着目し て, 作付されている飼料作物面積 $(864,493$ ha) と, 耕 作地の総面積（2,544,953 ha）は現状のまま維持するよ うに制約した。 さらに主食用米面積は 138 万 ha 以上と したが，これは日本の食用米需要を満たすうえで必要な面 積であると考えたためである（農林水産省 2010）。また 飼料用米の畜種ごとの供給割合は, 吉田 (2012) の報告 を参考に，ウシ，ブタ，ニワトリそれぞれ 15\%，42\%， 40\% と想定して, その配分をウシ, ブタ, ニワトリ用の 飼料用米作付面積に比例配分する制約を付加した。現実に は，現在の生産および加工の技術水準と加工費用を想定す れば, 飼料用米はすべて二ワトリに給与されることになる と予想されるが, 本研究では, 飼料用米の広範な畜産農家 への利用を促し，吉田（2010）の報告した値をこれから 飼料用米の導入を考えている畜産農家の飼料用米に対する 潜在的需要量と考え, 制約条件に加えることにした. なお, 本来なら全農スキーム分を考慮する必要があるが, 現時点 ではその情報を入手することができなかつたため, 吉田 （2010）の資料を参考に設定した。

\section{3. ベース条件に対する代替条件の設定}

本研究では，上記のべース条件に対して以下の代替条件 を設定した. 代替条件の第 1 と第 2 は, それぞれ余剩窒 素排出量と温室効果ガス排出量に, 政策的に削減目標が設 定された場合を仮定して，それぞれのケースで最適な家畜 頭羽数および耕作地面積を算出し，現在の制約値を 100 として環境影響削減率の計算を行った. 第 3 の代替条件 としては, 水田利用に関する補助金の影響を調べた. 現在, 飼料イネの補助金は 80,000 円/10a，水田における牧草作 付けの補助金は 35,000 円/10a と設定されているが，今 後補助金が削減された場合の最適な家畜頭羽数および耕作 地面積の配分を検討した．また, 第 4 の代替条件としては,
濃厚飼料の価格が現在より高騰した時の最適な家畜頭羽数 および耕作地面積を調べ，第 5 の代替条件では，畜種別 に飼料用米生産費が変化した場合の影響を調べた. なお, 第 5 の代替条件以外では, 耕種農家は飼料用米を生産す る段階でごの畜種に利用されるかは考慮していないので, ウシ, ブタおよびニワトリ用の飼料用米の生産費は等しい ものと仮定しているが，第 5 の代替条件では，実際に給 与する畜種によって加工コストが異なり, 生産費に違いが 生じることになるので，そのような畜種別の飼料用米価格 の違いが最適な家畜頭羽数および耕作地面積に及ぼす影響 を調べることを試みた，なお，飼料用米の流通経費や倉庫 料は条件によって大きく異なる可能性があるため, 本研究 では考慮しなかつた.

\section{結果および考察}

\section{1. ベース条件}

ベース条件における計算結果と現状の水準を表 2 に示 す.ここでは家畜頭羽数に関して, 乳用種の去勢肥育牛と 育成牛, 黒毛和種の繁殖牛と肥育牛, および $F_{1}$ 肥育牛と $F_{1}$ 育成牛の頭数が互いに関連性があるため, 簡素化して それぞれ乳用種去勢牛, 黒毛和種, $F$ として一つにまと めて表記した。

分析の結果, 最適条件下での黒毛和種, 採卵鷄およびブ ロイラ一の頭羽数は現状と比較して増加したのに対し, そ の他の家畜の頭数は減少し, 特に乳用種倠牛以外の家畜種 では下限制約值 $(-20 \%)$ まで減少した。耕作地面積に 関しては, 水田牧草面積は現状維持であったのに対し, 主 食用米の作付面積では下限値 $(-20 \%)$ となり, WCS の 作付面積が増加した。 粗飼料に関しては, 水田牧草ではな <WCS 生産が選択されたのは, 単位面積当たりのTDN 収量および利益（補助金も含めて）が水田牧草よりも WCSの方が大きかったためと考えられた.

ベ一ス条件における関連農家の利益の総計と環境負荷お よび労働時間の総計を示したのが表 3 である. ベース条 件における窒素排出量, 温室効果ガス排出量, エネルギ一 利用量は現状よりも，それぞれ 5.4\%，4.5\%，9.0\% 減少 し, その減少幅から環境影響においては温室効果ガス排出 量の制約が最も強く働くことが示された. 一方, 労働時間 の減少率は 0 で, 本研究において労働時間の制約が最も 大きいことが示された. またべ一ス条件における総利益が 現状の総利益よりも $10.1 \%$ 大きくなったことから, 家畜 頭羽数飼料作物の作付面積の枠組みを変えることで, 環 境影響と労働時間を現状の水準で維持しつつ, 関連農家の 総利益の向上を図ることができる可能性が示唆された，な お，この総利益の増加は，水田における飼料作物生産によ る補助金の増加が大きく寄与したものであった。

\section{2. 代替条件}

1）余剩窒素排出量の削減効果

現状において家畜からの排泄量と耕作地への窒素還元量 
耕畜連携システムの環境・経済性評価

Table 2 Comparison of the number of livestock and arable land between current situation and base simulation

\begin{tabular}{|c|c|c|c|c|c|c|c|}
\hline & $\begin{array}{l}\text { Holstein } \\
\text { (Milking cow) } \\
\text { (head) }\end{array}$ & $\begin{array}{l}\text { Holstein } \\
\text { (Steers) } \\
\text { (head) }\end{array}$ & $\begin{array}{c}\mathrm{JB}^{1} \\
\text { (head) }\end{array}$ & $\begin{array}{c}F_{1}^{2} \\
\text { (head) }\end{array}$ & $\begin{array}{c}\text { Pig } \\
\text { (head) }\end{array}$ & $\begin{array}{l}\text { Layer } \\
\text { (head) }\end{array}$ & $\begin{array}{l}\text { Broilers } \\
\text { (head) }\end{array}$ \\
\hline Current $^{3}$ & $1,467,000$ & 538,500 & $1,490,600$ & 631,606 & $8,220,430$ & $181,664,000$ & $102,987,000$ \\
\hline Base & $1,299,393$ & 430,099 & $1,788,720$ & 439,915 & $6,576,344$ & $217,996,000$ & $123,584,000$ \\
\hline \multirow[t]{2}{*}{ Change (\%) } & -11.4 & -20.0 & +20.0 & -30.0 & -20.0 & +20.0 & +20.0 \\
\hline & $\begin{array}{l}\text { Feed crops } \\
\text { (ha) }\end{array}$ & $\begin{array}{l}\text { Pasture in paddy } \\
\text { fields (ha) }\end{array}$ & WCS (ha) & $\begin{array}{c}\text { Feed rice } \\
\text { (For cattle) } \\
\text { (ha) }\end{array}$ & $\begin{array}{l}\text { Feed rice } \\
\text { (For pig) } \\
\text { (ha) }\end{array}$ & $\begin{array}{l}\text { Feed rice } \\
\text { (For poultry) } \\
\text { (ha) }\end{array}$ & Rice (ha) \\
\hline Current & 864,910 & 0 & 23,123 & 5,091 & 14,254 & 13,576 & $1,624,000$ \\
\hline Base & 864,910 & 0 & 250,772 & 4,836 & 13,540 & 12,895 & $1,398,000$ \\
\hline Change(\%) & 0 & 0 & $+1,084.5$ & -5.0 & -5.0 & -5.0 & -14.0 \\
\hline
\end{tabular}

'Japanese Black cattle

${ }^{2}$ Crossbreds of Japanese Black sire and Holstein dam

${ }^{3}$ Current situation

Table 3 Environmental impacts, labor time, and benefit under the current situation and base simulation

\begin{tabular}{lccccc}
\hline \hline & $\begin{array}{c}\text { Nitrogen surplus } \\
(1000 \mathrm{t})\end{array}$ & $\begin{array}{c}\text { GHG emission } \\
(1000 \mathrm{t})\end{array}$ & $\begin{array}{c}\text { Labor time } \\
\text { (million hour) }\end{array}$ & $\begin{array}{c}\text { Energy use } \\
(1000 \mathrm{GJ})\end{array}$ & $\begin{array}{c}\text { Benefit } \\
\text { (100 billion yen) }\end{array}$ \\
\hline Current & 361 & 47,642 & 942 & 199,990 & 15.97 \\
Base & 341 & 45,479 & 942 & 181,972 & 17.57 \\
\hline Change (\%) & -5.4 & -4.5 & 0 & -9.0 & +10.1 \\
\hline
\end{tabular}

${ }^{1}$ Current situation

のバランスは正の值であったことから，日本全体で見た場 合, 窒素は余剰であることが示された（表 3). そこで余 剩窒素排出量の削減目標を設定し, その削減目標が実現さ れたと仮定して, 余剰窒素排出量を現状から段階的に減少 させるシミュレーションを行つた. その結果, 余剩窒素排 出量削減率が $5 \%$ 以下では，家畜頭羽数はべ一ス条件と 同じであった（図 2) が，余剰窒素排出量の削減率が $6 \%$ を超えると, 乳用種雌牛, 乳用種去勢牛, $F_{1}$, ブロイラ一 および採卵鶏の頭羽数が減少し, さらに余剰窒素排出量の 削減率が $29 \%$ 以上では採卵鶏の羽数が下限値（-20\%） まで減少し，その後に黒毛和種とF 1 の頭数が大幅に減少 した. 一方, ブ夕の頭数は下限值 (-20\%) で一定であっ た.

他方, 耕作地面積に関しては, 余剩窒素排出量の削減率 が 28\% 以下では変化が見られなかったが, 29\% 以上に なるとWCS の耕作地面積が減少した。これは, 粗飼料 TDN 要求量の最も多い乳用種雌牛の頭数が減少し, 家畜 全体の粗飼料TDN 要求量が低下しためと考えられた.

さらに関連農家の総利益は，窒素排出量の削減率の限界 (41\%) まで削減したと仮定した時には 1,415,213 百万円 となり, 現状（1,597,299 百万円）よりも小さな値となつ た（この限界以上の削減率では解は得られなかった）。一 般に, 窒素排出量の削減率が大きくなるに伴つて, 関連農
家全体の利益は減少するが, 本研究の場合, 関連農家全体 の利益を維持した状態では $29 \%$ まで窒素を削減できる可 能性が示唆された.

2) 温室効果ガス排出量の削減効果

温室効果ガス排出量の削減率の増加に伴う最適な家畜頭 羽数と耕作地面積の推移を示したのが図 3 である。家畜 頭羽数においては, 温室効果ガス排出量の削減率が $4 \%$ 以 下では各畜種の頭羽数に変化が見られなかつたが，5\%以 上では乳用種雌牛および $F_{1}$ の頭数が減少した．さらに削 減率が 13\% を超えると黒毛和種の頭数が急激に減少し, 次いでブロイラ一および採卵鶏の羽数が減少した.しかし, ブ夕の頭数は温室効果ガス削減率と関係なく下限値で一定 であつた.このような結果から, 家畜頭羽数の増減の観点 から温室効果ガスを削減するには, 1 頭当たりのメタン排 出量の大きい乳用種雌牛や $F_{1}$ の頭数を減らすことが推奨 された.

他方, 耕作地面積に関しては, 温室効果ガス排出の削減 率が 8\%でWCSの耕作地面積が減少し，代わりに水田 牧草の耕作地面積が増加した。これは単位面積当たりの温 室効果ガス排出量が，水田牧草の方が，メタン排出量の多 いWCS 生産より小さいためと考えられた．さらに削減率 が高くなり $17 \%$ 以上になると水田牧草の耕作地面積も減 少し, 代わりに飼料用米の耕作地面積が増加した. このこ 

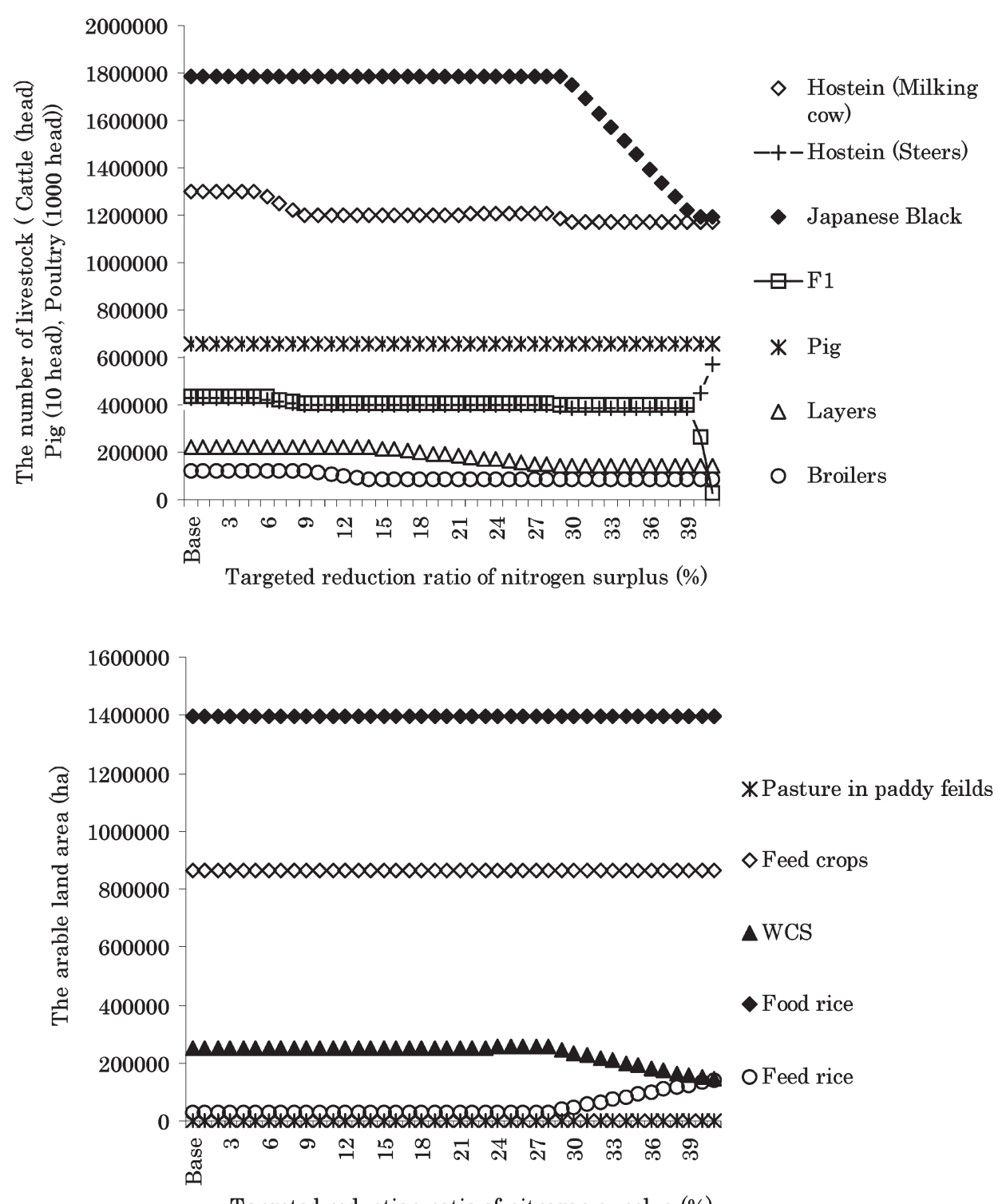

Figure 2 Optimum number of livestock and arable land in various targeted reduction ratio of nitrogen excretion

とは, 水田牧草生産の単位面積当たりの温室効果ガス排出 量は, 飼料用米生産より小さいものの, 水田牧草の耕作地 面積の増加によって飼養できるウシの頭数も増加し，その 結果, ウシからのメタン排出量が増加したためと推察され た.

温室効果ガス排出量を限界まで削減したと仮定した際 （削減率 19\%）の関連農家の総利益は 1,357,000 百万円 で，現状（1,597,299 百万円）よりも小さな值であった. しかしながら削減率が $18 \%$ の時の総利益は 1,435,859 百万円であることから，この削減率までは国家規模で各畜 種の頭羽数配分を変えることで, 現状の総利益を維持しつ つ, 温室効果ガスを削減できる可能性のあることが示唆さ れた.

\section{3）飼料イネ生産のための補助金の効果}

飼料イネ生産のための補助金の効果は表 4 に示すとお りである. なおブタおよびブロイラ一の頭羽数はシミュ レーションを通じて変化しなかったため, この表には揭載 しなかった.

飼料イネ社産のための補助金をべース条件の 80,000 円/10a から 55,000 円/10a まで減額しても, 水田の利活 用に变化は見られなかったが，補助金が 50,000 円/10a 以下になるとWCS の耕作地面積が減少し，代わりに水田 牧草の耕作地面積が増加した（表 4)。また補助金が 10,000 円/10a になると水田牧草の耕作地面積が減少し, 代わりに主食用米の耕作地面積が増加した.

他方, 家畜頭羽数においては, 補助金が 10,000 円/10a 

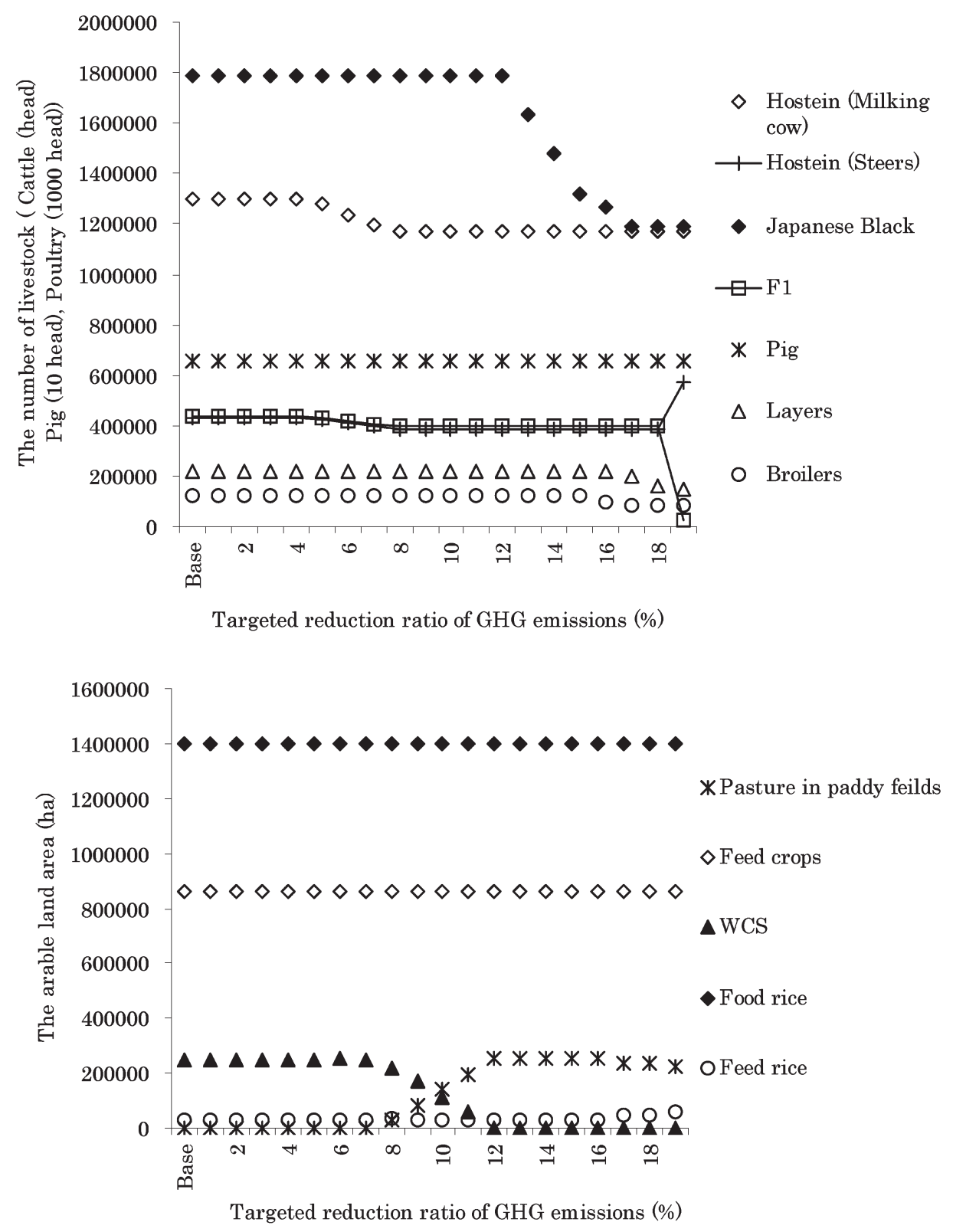

Figure 3 Optimum number of livestock and arable land in various targeted reduction ratio of GHG emission

になると乳用種雌牛の頭数が下限值（-20\%）まで減少 した，これは，補助金が低下して水田からの牧草生産が減 少し，その影響を乳用種雌牛が最も大きく影響を受けたた めと考えられた.

以上の結果から補助金が 55,000～50,000 円/10a 間に WCS を生産するメリットが消失する分岐点, 15,000 10,000 円/10a の間に水田牧草を生産するメリットが消 失する分岐点が存在していることが示された. 柳沢(2003) は，WCS 生産において収支のバランスを取るために必要 となる補助金価格は 46,000～57,000 円/10a と報告して いるが，本研究では補助金から生産費を差し引いた值が 0 となる補助金価格は57,500円/10a と予測されており,
本研究の結果は, 柳沢（2003）の報告と比べて少し高かつ たものの，妥当であると考えられた．また水田牧草から主 食用米へ移行する分岐補助金価格は WCS から水田牧草へ の分岐補助金価格よりもさらに小さかつた。このことから 現在の補助金が大幅に削減されない限り, 主食用米を生産 するよりも WCS や水田牧草などの粗飼料を生産する方が 関連農家の総利益は高くなり，農家経営には有利であるこ とが示唆された.

4）輸入濃厚飼料価格高騰の影響

現在, 曰本の畜産は輸入濃厚飼料に大きく依存している が，輸出国の食糧戦略や他の国際情勢から将来にわたって 安価な濃厚飼料を輸入し続けることができる保証はない 
西田 $\cdot$ 大石 $\cdot$ 長命 $\cdot$ 熊谷 $\cdot$ 広岡

Table 4 Comparison of optimum rations and benefit between various simulation

\begin{tabular}{|c|c|c|c|c|c|c|c|c|c|c|}
\hline & $\begin{array}{c}\text { Holstein } \\
\text { (Milking cow) } \\
\text { (million head) }\end{array}$ & $\begin{array}{c}\mathrm{JB}^{1} \\
\text { (million head) }\end{array}$ & $\begin{array}{c}\text { Layers } \\
\text { (million head) }\end{array}$ & $\begin{array}{l}\text { Pasture in paddy } \\
\text { fields (million ha) }\end{array}$ & $\begin{array}{c}\text { WCS } \\
\text { (million ha) }\end{array}$ & $\begin{array}{l}\text { Feed rice } \\
\text { (For cattle) } \\
\text { (ha) }\end{array}$ & $\begin{array}{l}\text { Feed rice } \\
\text { (For pig) } \\
\text { (ha) }\end{array}$ & $\begin{array}{l}\text { Feed rice } \\
\text { (For poultry) } \\
\text { (ha) }\end{array}$ & $\begin{array}{l}\text { Food rice } \\
\text { (million ha) }\end{array}$ & $\begin{array}{c}\text { Benefit } \\
\text { (100 billion yen) }\end{array}$ \\
\hline Current & 1.47 & 1.49 & 181.66 & 0.00 & 0.02 & 5,091 & 14,187 & 13,677 & 1.624 & 15.97 \\
\hline Base & 1.30 & 1.79 & 217.99 & 0.00 & 0.25 & 4,836 & 13,540 & 12,895 & 1.398 & 17.57 \\
\hline \multicolumn{11}{|c|}{ Subsidies for forage rice (10000 yen/10a) } \\
\hline 7.0 & 1.30 & 1.79 & 217.99 & 0.00 & 0.25 & 4,836 & 13,540 & 12,895 & 1.398 & 17.44 \\
\hline 5.5 & 1.30 & 1.79 & 217.99 & 0.00 & 0.25 & 4,836 & 13,540 & 12,895 & 1.398 & 16.87 \\
\hline 5.0 & 1.45 & 1.79 & 217.99 & 0.25 & 0.00 & 5,002 & 14,008 & 13,341 & 1.398 & 16.83 \\
\hline 1.5 & 1.45 & 1.79 & 217.99 & 0.25 & 0.00 & 5,002 & 14,008 & 13,441 & 1.398 & 16.21 \\
\hline 1.0 & 1.17 & 1.79 & 217.99 & 0.08 & 0.00 & 4,694 & 13,142 & 12,516 & 1.641 & 16.15 \\
\hline 0.0 & 1.17 & 1.79 & 217.99 & 0.00 & 0.00 & 4,694 & 13,105 & 12,481 & 1.650 & 16.11 \\
\hline \multicolumn{11}{|c|}{ Price of concentration (yen/kg) } \\
\hline 50 & 1.30 & 1.79 & 217.99 & 0.00 & 0.25 & 4,836 & 13,540 & 12,895 & 1.398 & 15.38 \\
\hline 88 & 1.17 & 1.79 & 217.99 & 0.00 & 0.23 & 6,631 & 18,567 & 17,683 & 1.398 & 7.2 \\
\hline 89 & 1.17 & 1.79 & 217.99 & 0.00 & 0.00 & 43,615 & 122,122 & 116,306 & 1.398 & 7.0 \\
\hline 100 & 1.17 & 1.79 & 217.99 & 0.00 & 0.00 & 43,615 & 122,122 & 116,306 & 1.398 & 5.0 \\
\hline 5.9 & 1.30 & 1.79 & 217.99 & 0.00 & 0.25 & 0 & 0 & 31,252 & 1.398 & 17.58 \\
\hline 6.0 & 1.30 & 1.79 & 217.99 & 0.00 & 0.25 & 31,277 & 0 & 0 & 1.398 & 17.58 \\
\hline \multicolumn{11}{|c|}{ Differences between pig and poultry for purchases costs of feed rice (yen/kg) } \\
\hline 5.6 & 1.30 & 1.79 & 217.99 & 0.00 & 0.25 & 0 & 0 & 31,252 & 1.398 & 17.58 \\
\hline 5.7 & 1.30 & 1.79 & 217.99 & 0.00 & 0.25 & 0 & 31,287 & 0 & 1.398 & 17.58 \\
\hline
\end{tabular}

Japanese Black cattle

（義平ら 2004）。輸入濃厚飼料の価格は 2007 年に大幅に 高騰し, 一時は 2008 年の金融危機で下落したものの, 米 国農務省需給見通しで, 輸出需要の増加と単収の低下によ り期末在庫率が下方修正されたことで再び上昇に転じ，現 在も期末在庫率が低水準である (JA 全農 2013) ことから, 今後も価格は高水準のまま推移することが予想される.

本研究の分析の結果, 濃厚飼料価格が上昇しても 88 円/ $\mathrm{kg}$ 以下では家畜頭羽数および耕作地面積に変化はみられ なかったが, 89 円 $/ \mathrm{kg}$ 以上になるとWCS の作付面積が 減少し, 代わりに飼料用米の作付面積が増加し, 同時に乳 用種雌牛の頭数が減少することが示された（表 4)。ここ で得られた 88 円 $/ \mathrm{kg}$ の濃厚飼料価格は, 現在の実勢価格 と比べてかなり高い水準で, この結果は, 濃厚飼料価格が 88 円 $/ \mathrm{kg}$ まで高騰したと仮定してはじめて, 飼料用米が 積極的に利用されることを示唆しており, 飼料用米を補助 金なしで普及するためには, かなりの生産コストの削減が 必要であると考えられた。

5）畜種別飼料用米生産コストの効果

飼料用米を家畜に給与する場合, 畜種によっては飼料用 米の加工が必要で, そのような加工コストを生産コストに 加える必要がある. 本研究のべ一ス条件では飼料用米生产 費は畜種に関係なく等しいと仮定していたが，より現実的 には，加工コストを加えた飼料用米生産費は畜種ごとに異 なることになり, 飼料用米の作付面積も異なることが予想 される，そこで，飼料用米生産配分に関する制約（ウシ $15 \%$ ，ブタ 42\%，ニワトリ 40\%）をなくし，ウシ用とブ 夕用のための加工コストはニワトリ用よりも高いと考え, ウシ用とブタ用の生産コストを増加させた時の最適家畜頭 羽数と作付面積の変化を表 4 に示している.

生産費を等しいとしたままで，畜種ごとの飼料用米生産
配分に関する制約をなくした予備的分析の結果, 飼料用米 が全て採卵鶏用に生産されることとなった，これは，家畜 の工ネルギ一要求量当たりの利益が採卵䳕で最も大きかっ たためと考えられる。一般に採卵鶏やブロイラ一生産にお いては, 籾米でも給与できるため加工が不要であり（農林 水産省 2011), 最も低コストで利用でき, 濃厚飼料との 代替率を高められる期待が大きい（吉田 2010）.

次に, ウシ用とブ夕用の飼料用米生産費を個別に変化さ せたところ, ウシ用飼料用米の生産費が二ワトリ用飼料用 米よりも 6.0 円 $/ \mathrm{kg}$ 以上安価であれば, ウシ用飼料用米を 作付けることが選択され, ブ夕用餙料用米の生産費が二ワ トリ用飼料用米よりも 5.7 円 $/ \mathrm{kg}$ 以上安価であれば，ブタ 用飼料用米の作付けが選択された．このことから，純粋に 経済性を考えた場合，ウシやブ夕に飼料用米を給与しよう とする場合, ニワトリよりもさらに安価に提供される必要 があると考えられた. この結果から, 今後, ウシやブタへ の飼料用米給与を実現されるためには, 安価に提供する分 を飼料用米の作付け（戦略作物助成）也飼料用米のわら利 用（耕畜連携助成）などの補助金の投入で補填し，主食用 米を生産した場合と同等の所得水準を確保するほか, 飼料 用米を摄取した家畜の畜産物の特性や機能を解明すること で付加価値を生じさせ，消費者への需要拡大をはかること も重要であると考えられた，その一例として，ブタに飼料 用米を給与することで, 豚肉の脂肪酸組成においてリノ一 儿酸が減少しオレイン酸が増加することが報告されている が（森山 1985），このような脂肪酸組成の違いに付加価 値をつけて販売できるのであれば, 付加価値の大きさ次第 では豚における利用も可能であると推察される.

\section{3. 本手法の応用と限界}

本研究では, 水田における飼料生産に焦点を当てて, 国 
家しべルでのモデル開発と政策提言を試みたが，本研究の 手法は, 家畜頭数や飼料作物の作付面積に関する統計值が 利用できれば, 都道府県や市町村の自治体しベルでも適用 が可能である. さらに, 目的関数の設定や制約条件の変更 によって, さまざまな条件を想定した分析が可能で, 応用 範囲は広いと考えられる。

しかしその一方で, 本研究では多くの仮定と単純化に よってモデルが構築されているが, 今後, より多くの情報 を収集し，モデルの改良を行っていく必要があると推察さ れる. どのようなモデルも, 完全なモデルはなく, 今後, さらなる研究の進展が不可欠である.

\section{補足説明}

本研究で仮定した線形計画モデルの技術係数行列と制約べ クトルの数值は以下の方法によって求めた.

\section{1. 利益}

ウシ, ブタ, 飼料作物および牧草の利益に関しては畜産物 生産費（農林水産省 2012b），二ワトリに関しては類型別営 農統計（農林水産省 2012c）を参考にし, 粗収益から労働費 と飼料費を含まない生産費を差し引いて求めた数値を利益と した. 作物生産の利益に関しては, 補助金（食用米に関して は販売価格も含む）から労働費を含まない生産費を差し引い て求めた. またWCS 生産の利益は, 農業・食品産業技術総 合研究機構（2008）の報告, 飼料用米生産の利益は農畜産業 振興機構（2009）の報告, 主食用米生産の利益は米及び麦類 の生産費（農林水産省 2012d）を参考にした．ただし，飼料 作物生産からの販売費は家畜生産の飼料費によって相殺され ると仮定して, これらの費目はモデルに含めなかった，なお 現在作付けしている国産飼料作物に関しては, その生産量の うちの水田の利用がごの程度行われているか不明のため, 補 助金は考慮しなかった.

\section{2. 家畜の給与飼料成分と摂取量}

水田牧草および飼料作物に含まれている牧草はイタリアン ライグラスを想定し, 輸入飼料に関して, 肉牛の濃厚飼料は Ogino 5 （2004）が採用した飼料組成, 乳牛と F 1 の濃厚飼 料は西田ら（2013）の聞き取りから得られた飼料組成を参考 にして設定し, 購入粗飼料は Ogino ら（2004）の報告で設 定されている乾草を参考にした. ブタの購入飼料の組成は Ogino ら（2013）の報告を参考にし，二ワトリの購入飼料 の組成は脇と村野（2009）の報告を参考にして設定した。

エネルギー要求量に関して, ウシおよびブタにおいては可 消化養分総量 (TDN) を考慮し, ニワトリにおいては代謝工 ネルギー (ME) を考慮した. ウシの濃厚飼料と粗飼料別の $T D N$ 要求量は各都道府県の乳牛, 肉用牛近代化計画を参考に し, 平均値を利用した. ブタの TDN 要求量は日本飼養標準 豚 (2005 年版)（農業・食品産業技術総合研究機構 2005) を参考に, また二ワトリのME 要求量は日本飼養標準家禽（農 業・食品産業技術総合研究機構 2011）を参考にした.

日畜会報 $84(4) ： 475-486,2013$

\section{3. 作物生産}

現在作付している国産飼料作物に関しては, 牧草 (イタリ アンライグラス), 青刈りトウモロコシおよびソルゴーを考慮 した. 飼料作物の面積当たりの技術係数行列の数値は牧草 (イ タリアンライグラス), 青刈りトウモロコシおよびソルゴーの 技術係数行列の数値を現在のそれぞれの作物の作付面積（牧 草は755,100 ha, 青刈りトウモロコシは92,200 ha, ソルゴー は 17,600 ha）で加重平均して求めた. 作物の収量に関して, 牧草, 青刚りトウモロコシおよびソルゴーは作物統計（農林 水産省 2012a）を参考にして, それぞれ 3,500 kg/10a, 5,110 kg/10a および5,340 kg/10a とした. WCS は広岡5 (2008) の報告を参考にし, 乾物収量で $1,000 \mathrm{~kg} / 10 \mathrm{a}$ とし, 飼料用 米は中野（2011）を参考にし, 原物収量で $546 \mathrm{~kg} / 10 \mathrm{a}$ とし た. また現状の家畜頭羽数および面積に関して, 家畜頭羽数 は畜産統計（農林水産省 2012e）を参考にし，飼料作物およ び主食用米は作物統計（農林水産省 2012a）を参考にし，飼 料イネに関しては谷口（2012）を参考にした。

一方, 水田牧草, WCS, 飼料用米, 飼料作物 1 ha 当たり のエネルギー供給量は, 収量にエネルギー含有率を乗じて算 出した．ただし作物当たりのエネルギー含有率は日本標準飼 料成分表（農業·食品産業技術総合研究機構 2009）を参考 にした.

\section{4. 窒素収支}

家畜が排出した窒素はウシで $13.7 \%$ ，ブタで $24.2 \%$ ，二ワ トリで $51.5 \%$ 揮散すると仮定し (寶示戸5 2003), 残りの窒 素は堆肥として作物生産に利用されると仮定した，家畜およ びニワトリ1頭羽当たりの䔬尿中窒素量は築城と原田 (1997) の報告を参考にして設定した．また，各畜種からの堆肥はま とめて飼料作物生産のための土地に還元されると仮定し, 本 研究では, 肥効率と化学肥料に対する代替率を家畜部門で考 慮した. なお, 肥効率および代替率は家畜ふん堆肥の品質評価. 利用マニュアル（農業・生物系特定産業技術研究機構 2004) を参考にし，肥効率はウシで $30 \%$, ブタで $50 \%$ ，ニワトリ で 70\%とし，代替率はウシで 30\%，ブタで60\%，ニワトリ で60\%とした.

牧草, 青刈りトウモロコシおよび主食用米の 1 ha 当たりの 窒素必要量は家畜ふん堆肥の品質評価·利用マニュアル (農業. 生物系特定産業技術研究機構 2004), WCS は稻発酵粗飼料 生産・給与技術マニュアル（農林水産省 2011）を参考にし, 飼料用米の窒素必要量はWCS と同等とした．また，以上の 作物生産では堆肥を最大限利用することを想定したが, 食用 米に関しては現実の堆肥の利用を想定した. すなわち, 食用 米に関しては, 西尾 (2003) の報告における水田に投入され た総堆肥量から, 1 ha 当たりの窒素必要量を算出した. ソル ゴーに関してはデータが存在していなかったため, 青刈りト ウモロコシと同等とした.

\section{5. 温室効果ガス排出量およびェネルギー利用量}

ウシ 1 頭 1 年当たりの温室効果ガス排出量およびエネル ギー利用量は Ogino $5(2004,2007,2008)$ を参考に, ブ 
タは Ogino 5 (2013)，採卵䳕は Dekker 5 (2011), ブロ イラーはPelletier (2008) の報告をそれぞれ参考にした. た だし家畜管理および排泄物処理によって排出される温室効果 ガス排出量およびエネルギ一利用量のみ考慮し，飼料生産お よび飼料輸送によって排出される温室効果ガスは考慮しな かった．作物生産によって排出される温室効果ガス排出量お よびエネルギー利用量は LCA 手法を用いた農作物栽培の環 境影響評価実施マ二ュアル（農業環境技術研究所 2003）を 参考にした．ただしWCS および飼料用米生産に対するエネ ルギ一消費量は農林水産省（2010）の低コスト生産の事例を 参考にし，主食用米の $30 \%$ 減とした。 また購入飼料 $1 \mathrm{~kg}$ 当 たりの温室効果ガス排出量およびエネルギー利用量は Ogino ら（2008）の報告のインベントリを参考にして計算した.

\section{6. 労働時間}

ウシおよびブタの生産に対する労働時間は畜産物生産費 (農 林水産省 2012b）を参考にし，二ワトリに関しては類型別営 農統計（農林水産省 2012c）を参考にした。主食用米生産に おける労働時間は米及び麦類の生産費（農林水産省 2012d）, WCS 生産に対する労働時間は柳沢（2003）を参考にした. また飼料用米生産における労働時間は農林水産省（2010）の 低コスト生産の事例を参考にし，主食用米の30\% 減とした。 青刈りトウモロコシおよびソルゴー生産に対する労働時間は 粗飼料・草地八ンドブック（高野ら 1989）を参考にし, 牧 草生産の労働時間は青刈りトウモロコシおよびソルゴーの平 均値を用いた。

\section{謝 辞}

本研究の一部は日本生命財団環境問題個別研究助成の援 助によって行われたものである. 記して感謝する.

\section{文献}

Dekker SEM, de Boer IJM, Vermeij I, Aarnink AJA, Groot Koerkamp PWG. 2011. Ecological and economic evaluation of Dutch egg production systems. Livestock Science 139, 109-121.

藤本高志，恒川磯雄．2007。飼料用稲を機軸とする耕畜連携シス テム導入の費用と便益：飼料自給・貲尿循環利用・水田保全 に及ぼす影響の経済評価。農業経営研究 45，1-11。

Herrero M, Thornton PK, Notenbaert AM, Wood S, Msang $S$. Freeman HA, Bossio D, Dixon J, Peters M, van der Steeg J, Lynam J, Partharathy Rao P, MacMillan S, Gerard B, McDermott J, Sere C, Rosegrant M. 2010 Smart investiments in sustainable food production : Revising mixed crop-livestock systems. Science $\mathbf{3 2 7}$, $822-855$

広岡博之, 石川哲也, 草佳那子, 石田元彦. 2008. 飼料个ネ祇有産 と結びついた肉用繁殖生産システムの窒素の利用性と循環性 に関するモデル分析．日本畜産学会報 80, 17-25.

広岡博之, 大石風人. 2010。稲発酵粗飼料在利用した肉用牛肥育 生産に関する最適飼料設計。日本畜産学会報 81，333-343.

寶示戸雅之, 池口厚男, 神山和則, 島田和宏, 荻野暁史, 三島慎 一郎，賀来康一，2003、我が国農耕地における窒素負荷の都 道府県別評価と改善シナリオ. 日本土壌肥料学雑誌 $74,467-$
474.

因野要一，石塚 讓，中西直人，押部明徳，三津本充，松崎正敏， 柴 伸弥, 高平寧子, 宮島恒晴, 宮原雅明, 入江正和. 2007. 飼料イネを給与した肥育牛の筋肉および脂肪中ビタミン A お よびE 含量. 近畿中国四国農業研究 10, 47-53.

JA 全農. 2013. 配合飼料情勢. [homepage on the internet]. JA 全農, 東京 ; [cited 6 January 2013]. Available from URL : http : //jaccnet.zis-ja.com/d1080000000/ d1080100000/back-number.html

勝俣昌也，佐々木啓介，斉藤真二，石田藍子，京谷隆侍，本山三 知代，大塚 誠，中島一喜，三津本充. 2009. 肥育後期豚へ の玄米の給与が皮下脂肪の性状に及ぼす影響. 日本畜産学会 報 80, 63-69.

Kikuhara K, Hirooka H. 2009. Application of a simulation model for dairy cattle production systems integrated with forage crop production: the effects of whole crop rice silage utilization on nutrient balances and profitability. Asian-Australasian Journal of Animal Science 22, 216-224.

小林博史, 柳川道夫. 1984. 豚の内質改善に関する試験（第 5 報） 飼料用米の給与が豚肉質に及ぼす影響。埼玉県畜産試験場研 究報告 22, 71-77

古賀照章, 大久保吉啓, 久保田和弘, 唐沢哲哉, 岸本 剛, 田中 章人. 2003．飼料イネの籾または穂を泌乳牛および乾乳牛へ 給与した場合の消化率。長野県畜産試験場研究報告 $\mathbf{3 0}, 1-5$.

森山則男, 高橋寿道, 原島昇晃, 五十嵐真哉, 藤井孝文. 1985. 肥育豚に対するモ三米給与。新潟県畜産試験場研究報告 $\mathbf{6}$, 133-138.

中野真理. 2011. 飼料用米の現状と課題. 調査と情報一ISSUE BRIEF-716. [homepage on the Internet]. 国立国会図書 館, 東京 ; [cited 6 January 2013]. Available from URL http : //warp.da.ndl.go.jp/info:ndljp/pid/2800346/ www.ndl.go.jp/jp/data/publication/issue/pdf/0716. pdf

Naylor R, Steinfeld H, Falcon W, Galloway J, Smil V, Bradford E, Alder J, Mooney H. 2005. Losing the links between livestock and land. Science 310, 1621-1622.

西田俊也, 小栗道政, 大石風人, 長命洋佑, 熊谷 元, 荻野暁史, 広岡博之. 2013. 環境負荷と経済性の両面から見た交雑種 $\left(F_{1}\right)$ 生産における持続可能性の評価。日本畜産学会報 84, 191201.

西尾道徳. 2003. 統計デー夕に基づく家畜ふん尿窒素のフローシー 卜亡土壤負荷原単位の推定. 日本土壤肥料学雑誌 74, 721730.

農畜産業振興機構. 2009. 飼料用米生産の現状とコストダウンの 可能性. [homepage on the Internet]. 農畜産業振興機構, 東京 ; [cited 6 January 2013]. Available from URL : http : //lin.alic.go.jp/alic/month/domefore/2009/oct/spe-01. htm

農業・食品産業技術総合研究機構. 2009. 日本標準飼料成分表. 中央畜産会, 東京.

農業環境技術研究所. 2003。 LCA 手法を用いた農作物栽培の環 境影響評価実施マニュアル。「環境研究」環境影響評価のため のライフサイクルアセスメントの開発. 研究成果報告書別冊. [homepage on the Internet]. 農業環境技術研究所, 東京: [cited 06 January 2013]. Available from URL : http : //www.niaes.affrc.go.jp/project/lca/lca_m.pdf

農業·生物系特定産業技術研究機構. 2004. 家畜ふ九堆肥の品質 評価・利用マ二ュアル. 農業·生物系特定産業技術研究機構, 東京. 
農業·食品産業技術総合研究機構. 2005. 日本飼養標準 (豚). 中央畜産会，東京。

農業·食品産業技術総合研究機構. 2008. 飼料用稲導入の背景と 耕種・畜産部門の経済性. [homepage on the Internet]. 農業・食品産業技術総合研究機構, 東京; [cited 6 January 2013]. Available from URL : http : //www.naro.affrc. go.jp/publicity_report/publication/files/manual_ paddy200804_01.pdf

農業·食品産業技術総合研究機構. 2011. 日本飼養標準 (家禽). 中央畜産会, 東京.

農林水産省. 2010. 米粉用米・飼料用米の生産をめぐる状況. [homepage on the Internet]. 農林水産省, 東京; [cited 6 January 2013]. Available from URL : http : //www. maff.go.jp/j/seisan/ryutu/info/pdf/100331 mj.pdf

農林水産省. 2011. 稲発酵粗飼料生産・給与技術マ二ュアル. 日 本草地畜産種子協会, 東京.

農林水産省. 2012a. 平成 22 年 作物統計. 農林統計協会, 東京.

農林水産省. 2012b. 平成 22 年 畜産物生産費. 農林統計協会, 東京.

農林水産省. 2012c. 平成 22 年 類型別営農統計. 農林統計協会, 東京.

農林水産省. 2012d. 平成 22 年 米及び麦類の生産費. 農林統 計協会, 東京.

農林水産省. 2012e. 平成 22 年 畜産統計. 農林統計協会, 東京.

Ogino $A$, Ishida $M$, Ishikawa $T$, Ikeguchi $A$, Waki $M$, Yokoyama H, Tanaka Y, Hirooka H. 2008. Environmental impacts of a Japanese dairy farming system using whole-crop rice silage as evaluated by life cycle assessment. Animal Science Journal 79, 727-736.

Ogino A, Kaku K, Osada T, Simada K. 2004. Environmental impacts of Japanese beef-fattening system with different feeding length as evaluated by life-cycle assessment method. Journal of Animal Science $\mathbf{8 2}$ 2115-2122.

Ogino A, Orito H, Shimada K, Hirooka H. 2007. Evaluating environmental impacts of the Japanese beef cowcalf system by the life cycle assessment method. Animal Science Journal 78, 424-432.
Ogino A, Osada T, Takada R, Takagi T, Tsujimoto S, Tonoue T, Matsui D, Katsumata M, Yamashita T, Tanaka Y. 2013. Life cycle assessment of Japanese pig farming using low-protein diet supplemented with amino acids. Soil Science and Plant Nutrition 59, 107118.

Pelletier N. 2008. Environmental performance in the US broiler poultry sector: Life cycle energy use and greenhouse gas, ozone depleting, acidifying and eutrophying emissions. Agricultural Systems 98, 6773.

Russelle MP, Entz MH, Franzluebbers AJ. 2007. Reconsidering integrated crop-livestock systems in North America. Agronomy Journal 99, 325-334.

Schiere JB, Ibrahim MNM, van Keulen H. 2002. The role of livestock for sustainability in mixed farming : criteria and scenario studies under varying resource allocation. Agriculture Ecosystem Environment $\mathbf{9 0}$, 139-153.

千田雅之, 荻野暁史. 2012. 水田飼料資源を利用した子牛生産の LCA による環境影響評価. 日本農業経済学会論文集 267274.

高野信雄, 佳山良正, 川鍋祐夫. 1989. 粗飼料·草地八ンドブッ ク. pp. 382-383. 養賢堂, 東京.

谷口信和. 2012. 飼料用米 . WCS 用稲生産の本格的な展開へ. 畜産コンサルタント 48, 12-16.

築城幹典, 原田靖生. 1997. 家畜の排泄物量プログラム. システ 么農学 13, 17-23

柳沢淳二. 2003. 飼料イネの栽培実証事例における稲発酵飼料の 生産と収益性. 愛知県農業総合試験場研究報告 35, 43-50.

吉田宣夫. 2010. 飼料用米の研究と普及の状況について. 日本畜 産学会報 81, 489-493.

義平大樹, 荒木和哉, 中司啓二.2004. 世界各地から収集した秋 播ライコムギの北海道における生育特性第 1 報 : 有望品種と 低収品種の収量関連形質の比較. 酪農学園大学紀要 28, 233244.

脇 雅之, 村野多可子. 2009. 飼料用米の採卵鶏への給与. 千葉 県畜産セン夕一研究報告 9 , 5-8. 


\section{Environmental and economic evaluation for integration systems between crop and animal production using linear programming — Utilization of paddy rice fields at national level-}

Toshiya NISHIDA' ${ }^{1}$, Kazato OISHI', Yousuke CHOUMEI', Hajime KUMAGAI and Hiroyuki HIROOKA ${ }^{1}$

${ }^{1}$ Graduate School of Agriculture, Kyoto University, Sakyo, Kyoto 606-8502, Japan

Corresponding : Hiroyuki HIROOKA (fax : +81 (0) 75-753-6363, e-mail : hirooka@kais.kyoto-u.ac.jp)

A linear programming (LP) model was used to evaluate integration between animal and crop production systems at national level. In particular, this evaluation focused on the utilization of paddy rice field. Animal categories considered were production systems for Holstein cows (milking and dry cows and replacement heifers), Holstein growing calves, dairy fattening steers, Japanese Black cowcalves, Japanese Black fattening steers, fattening $F_{1}$ steers and heifers, integrated pigs, layers and broilers, and crop categories were feed production for pasture, whole crop rice silage (WCS), feed rice for animals and food rice for human. In addition, external concentrates and roughages were considered. The objective function of the model maximizes total benefits from animal and crop production, while restricting environmental impacts (surplus nitrogen, greenhouse gas emissions, and energy use) and total labor time at national level. The result of optimization for the basic situation suggested that the total benefit may be maximized when the number of Japanese Black and layer increased and the number of other animals decreased and when forage rice for WCS was cultivated instead of food rice. The effects of alternative scenarios such as targeted reduction of surplus nitrogen and green house gas, the amount of subsidies of feed rice in paddy fields, concentrate costs and different processing costs for each animal category in feed rice production on optimization of integration between animal and crop production were also examined.

Nihon Chikusan Gakkaiho 84 (4), 475-486, 2013

Key words : benefit, environmental impact, integration between crop and animal production, linear programming, paddy field. 